\title{
Analysis of the Influence of Agricultural Climatic Conditions on the Allocation of Labor Resources in Agriculture
}

\author{
Bayarma Dashieva $^{1},{ }^{*}$ Anna Ukolova ${ }^{1}$ \\ ${ }^{I}$ Russian State Agrarian University - Moscow Timiryazev Agricultural Academy, Russia \\ "Email: dashieva.b.sh@rgau-msha.ru
}

\begin{abstract}
The article studies the influence of agricultural climatic conditions on the distribution of agricultural labor resources in the territory of the Russian Federation using the methods of analytical and typological groupings. The study, as expected, showed that agricultural climatic conditions play a decisive role in the location and specialization of agricultural production, and also affect the distribution of agricultural labor resources. The using of the Cobb-Douglas production function showed that labor resources are a priority factor for agricultural production. To ensure the geopolitical security of the country, preserve rural areas and increase the number of agricultural labor resources at the state level, it is necessary to stimulate the development of agricultural production, taking into account the results of typification, and pay special attention to groups of regions with unfavorable agricultural climatic conditions.
\end{abstract}

Keywords: Agricultural climatic conditions, Grouping method, Rural population, Agriculture, Sum of temperatures, Labor resources, Number of employed.

\section{INTRODUCTION}

Labor resources are one of the prime factors influencing the results of agricultural production. The efficient use of labor resources of the rural population leads to the improvement in the demographic situation, the preservation of rural areas [1], reduction of the urbanization, maintenance of the necessary standard of the rural way of life. Agriculture remains the main sphere of employment in rural areas. The use of labor resources in agriculture has its own characteristics: dependence on climatic conditions and land quality, high seasonality, low prestige of labor, low wages, poor social infrastructure in the countryside, compared to the city [2].

The regions of the Russian Federation are characterized by a variety of climatic zones and therefore there is a need to group regions by agricultural climatic resources. The development of the grouping will make it possible to assess the influence of agricultural climatic conditions on the differences in the distribution of agricultural labor resources by the subjects of the Federation, and then, based on the results of the analysis, to develop the necessary measures of state regulation [3]. Agricultural climatic resources are the climatic properties ensuring the agricultural production: heat, moisture and light. The main agricultural climatic indicator determining the heat resources and the need for them of agricultural crops is the heat supply infrastructure for growing season determined by the sum of active temperatures above $10^{\circ} \mathrm{C}$, because during the period with such a temperature, active growing of crops occurs.

\section{RESEARCH METHODOLOGY}

For the typification of regions, a typological grouping was carried out on the basis of an intermediate analytical one.

As a factor reflecting the differences in the thermal resources of the regions, the average sum of temperatures for micro regions of the constituent entities of the Russian Federation for the period with temperatures above $10^{\circ} \mathrm{C}$ was chosen. The lower the latitude and the lower the absolute height of the area, the greater the sum of the air temperature above $10^{\circ} \mathrm{C}$ in the region. The studied 
population included 79 regions of the country (the Nenets Autonomous Region, the Khanty-Mansi Autonomous Region - Yugra, the Yamalo-Nenets Autonomous Region were taken into account as part of their regions. The federal cities (Moscow, St. Petersburg and Sevastopol) were not included in the study.

The number of groups was determined by the Sturgess formula (1):

$m=1+3.322 * \lg 79=7.3 \approx 8$

First, according to the grouping criterion, the average sum of temperatures by micro regions of the constituent entities of the Russian Federation for the period with temperatures above $10^{\circ} \mathrm{C}$ is built as ranked distribution series and, for clarity, is shown graphically as statistics percentile curve (ogive). According to the Figure, six groups of regions were identified by searching the highquality transitions and two groups determining the interval step. Then, taking into account the signs characterizing the labor resources of agriculture, the groups were consolidated and the types of regions were identified.

To assess the impact of labor supply and investment on the level of agricultural production, the Cobb-Douglas production function was created:
$Q=A * L^{\alpha} * K^{\beta}$,

which characterizes the dependence of gross value added in basic prices by the type of economic activity "Agriculture, forestry, hunting, fishing and fish farming" $(Q)$ on the number of people employed in agricultural production for all categories of farms $(L)$ and investments in capital assets directed for the development of agriculture $(K)$. All indicators are taken per 100 hectares of agricultural land used by enterprises, organizations and citizens engaged in agricultural production.

The matching correlation coefficient between investments in capital assets and the number of employees was 0.52. Therefore, we can talk about the absence of collinearity of the factors and the possibility of including two factors in the model at the same time.

This model is nonlinear in parameters, and is brought to a linear form by taking the logarithm:

$\ln Q=\ln A+\alpha \ln L+\beta \ln K$

Estimates of the model parameters are determined using OLS.

The regression equation was drawn up for 69 regions. Regions with sharply differing values of indicators from the entire population and regions with unplaced data on

Table 1. Grouping of constituent subjects of the Russian Federation by the average sum of temperatures for a period with temperatures above $10^{\circ} \mathrm{C}$

\begin{tabular}{|c|c|c|}
\hline $\begin{array}{l}\text { Groups of subjects } \\
\text { by the average sum } \\
\text { of temperatures for a } \\
\text { period with } \\
\text { temperatures above } \\
10^{\circ} \mathrm{C}\end{array}$ & $\begin{array}{l}\text { Number } \\
\text { of } \\
\text { subjects }\end{array}$ & Names of subjects of the Russian Federation \\
\hline under 1750 & 22 & $\begin{array}{l}\text { Regions: Arkhangelsk, Vologda, Irkutsk, Leningrad, Magadan, Murmansk, } \\
\text { Sakhalin, Sverdlovsk, Tomsk, Tyumen. } \\
\text { Territories: Transbaikal, Kamchatka, Krasnoyarsk, Perm. } \\
\text { Republics: Altai, Buryatia, Karelia, Komi, Sakha (Yakutia), Tyva, Khakassia. } \\
\text { Autonomous Regions: Chukotka. }\end{array}$ \\
\hline $1750-2600$ & 41 & $\begin{array}{l}\text { Regions: Amur, Kemerovo, Kostroma, Novosibirsk, Pskov, Ivanovskaya, } \\
\text { Chelyabinsk, Omsk, Vladimir, Smolensk, Novgorod, Kirov, Tver, Yaroslavl, } \\
\text { Kurgan, Moscow, Nizhny Novgorod, Kaluga, Tula, Kaliningrad, Bryansk, } \\
\text { Ryazan, Oryol, Ulyanovsk Penza, Kursk, Lipetsk, Tambov, Orenburg, Samara } \\
\text { Territories: Altai, Primorsky, Khabarovsk. } \\
\text { Republics: Bashkortostan, Mari El, Mordovia, Karachay-Cherkess, Tatarstan, } \\
\text { Udmurt, Chuvash. } \\
\text { Autonomous province: Jewish. }\end{array}$ \\
\hline over 2600 & 16 & $\begin{array}{l}\text { Regions: Astrakhan, Belgorod, Volgograd, Voronezh, Rostov, Saratov. } \\
\text { Territories: Krasnodar, Stavropol. } \\
\text { Republics: Adygea, Dagestan, Ingushetia, Kabardino-Balkarian, Crimea, } \\
\text { Kalmykia, North Ossetia - Alania, Chechen. }\end{array}$ \\
\hline
\end{tabular}


investments in capital assets were excluded from the studied population in order to ensure the confidentiality of primary statistical data received from organizations.

\section{RESEARCH RESULTS}

\subsection{Typological grouping}

The first typological group (table 1) includes regions with the average sum of temperatures up to $1750^{\circ} \mathrm{C}$; regions of the second group with the average sum of temperatures from 1750 to $2600^{\circ} \mathrm{C}$ prevail, and the third group of regions is represented by regions with the average sum of temperatures over $2600^{\circ} \mathrm{C}$.

The first group included the regions of the North of Russia, the North-Western part, Ural, parts of the Far
East, Eastern and Western Siberia with unfavorable natural and climatic conditions and poor development of agriculture, with a large volume of subsidies for agricultural organizations, but with a large gross added value in agriculture per capita of the rural population and small lags of agricultural wages from the average wages in the region (table 2).

The second largest group is represented by the regions of the Center of Russia, the Volga region, part of the Urals and part of Western Siberia, part of the Far East. It has more favorable conditions for farming in comparison with the first group and this group of regions is characterized by the highest average score of potential climate productivity and the largest volume of investment in fixed assets per capita of the rural population, aimed at the development of agriculture.

Table 2. Indicators characterizing the level of development of agriculture by groups of regions of the Russian Federation (per region)

\begin{tabular}{|c|c|c|c|c|}
\hline \multirow{2}{*}{ Indicator } & \multicolumn{3}{|c|}{ Group } & \multirow{2}{*}{$\begin{array}{l}\text { Total and } \\
\text { average }\end{array}$} \\
\hline & 1 & ॥ & III & \\
\hline Number of regions & 22 & 41 & 16 & 79 \\
\hline \multicolumn{5}{|l|}{ Per region: } \\
\hline average score of potential climate productivity & 86 & 132 & 126 & 118 \\
\hline $\begin{array}{l}\text { area of agricultural land used by enterprises, organizations and } \\
\text { citizens engaged in agricultural production, thousand hectares }\end{array}$ & 1365 & 2604 & 3509 & 2442 \\
\hline resident rural population, thousand people & 307 & 435 & 789 & 471 \\
\hline \multicolumn{5}{|c|}{$\begin{array}{l}\text { Per } 100 \text { hectares of agricultural land used by enterprises, organizations and citizens engaged in agricultural } \\
\text { production }\end{array}$} \\
\hline $\begin{array}{l}\text { Gross value added in basic prices by type of economic activity } \\
\text { "Agriculture, forestry, hunting, fishing and fish farming", thousand } \\
\text { rubles }\end{array}$ & 28543 & 2506 & 3261 & 9910 \\
\hline $\begin{array}{l}\text { The number of people employed in agriculture for all categories of } \\
\text { farms, people }\end{array}$ & 44 & 31 & 42 & 37 \\
\hline $\begin{array}{l}\text { Investments in capital assets aimed at the development of } \\
\text { agriculture, thousand rubles }\end{array}$ & 719 & 266 & 304 & 400 \\
\hline $\begin{array}{l}\text { Agricultural production in farms of all categories at actual prices } \\
\text { (according to OKVED (Russian National Classifier of Types of } \\
\text { Economic Activity)), thousand rubles }\end{array}$ & 5195 & 3352 & 5104 & 4220 \\
\hline Share of the rural population in the total population, $\%$ & 27 & 28 & 42 & 31 \\
\hline Ratio of wages in agriculture to average wages in the region, $\%$ & 85 & 81 & 76 & 81 \\
\hline $\begin{array}{l}\text { Gross value added in basic prices for OKVED "Agriculture, } \\
\text { forestry, hunting, fishing and fish farming" per capita of the rural } \\
\text { population, thousand rubles. }\end{array}$ & 256 & 104 & 101 & 145 \\
\hline $\begin{array}{l}\text { Investments in capital assets aimed at the development of } \\
\text { agriculture, on a per capita rural population basis, thousand rubles }\end{array}$ & 5 & 16 & 9 & 12 \\
\hline $\begin{array}{l}\text { Budget subsidies that are attributed to the results of financial and } \\
\text { economic activities of agricultural organizations, per organization, } \\
\text { mln rubles }\end{array}$ & 19 & 9 & 7 & 12 \\
\hline
\end{tabular}


Table 3. Indicators characterizing the distribution of agricultural labor resources by regions of the Russian Federation (per region)

\begin{tabular}{|c|c|c|c|c|}
\hline \multirow{2}{*}{ Indicator } & \multicolumn{3}{|c|}{ Group } & \multirow{2}{*}{$\begin{array}{l}\text { Group III to } \\
\text { Group I } \\
\text { relationship }\end{array}$} \\
\hline & | & II & III & \\
\hline $\begin{array}{l}\text { Average annual number of employees of } \\
\text { agricultural orga } \\
\text { nizations employed in agricultural production, } \\
\text { thousand people }\end{array}$ & 7,9 & 15,8 & 21,1 & 2,7 \\
\hline $\begin{array}{l}\text { Average annual number of workers of peasant } \\
\text { (farmer) agricultures and individual entrepreneurs } \\
\text { engaged in agricultural production, thousand } \\
\text { people }\end{array}$ & 1,7 & 2,6 & 9,0 & 5,1 \\
\hline $\begin{array}{l}\text { Number of people employed in performing } \\
\text { agricultural work in private household plots and } \\
\text { other individual farms, thousand people }\end{array}$ & 318 & 538 & 720 & 2,3 \\
\hline $\begin{array}{l}\text { Share of the average annual number of people } \\
\text { employed in agriculture, forestry, hunting and } \\
\text { fishing in the total number of people employed, } \%\end{array}$ & 6,4 & 8,5 & 14,2 & 2,2 \\
\hline
\end{tabular}

Agriculture is most strongly developed in the third group, represented by the southern regions, with the most favorable agricultural climatic conditions. But at the same time, there are regions with an increased temperature background, which leads to the formation of droughts of medium and strong intensity. This group contains the largest area of agricultural land used by enterprises, organizations and citizens engaged in agricultural production, and the largest share of the rural population.

From group to group with an increase in the average sum of temperatures, the proportion of those employed by the type of economic activity "Agriculture, forestry, hunting and fishing" increases due to the increase in the proportion of the rural population due to favorable conditions for farming. The average annual number of employees of agricultural organizations engaged in agricultural production in the third group compared to the first is 2.7 times higher than the first, the average annual number of farm workers and individual entrepreneurs engaged in agricultural production is 5.1 times higher, and the number of people employed in agricultural work in private household plots and other individual households of citizens - 2.3 times more (table 3 ). This suggests that climatic conditions determine the specialization of agricultural production, which in turn affects the distribution of labor resources.

\subsection{Cobb-Douglas production function}

From the second to the third group in the table 2, there is an increase in the level of agricultural production depending on the growth in the level of investment and the availability of labor resources per unit area; it is possible to describe this dependence using the production function of Cobb-Douglas.

Equation of dependence of gross value added in basic prices for the type of economic activity "Agriculture, forestry, hunting, fishing and fish farming" $(Q)$ on the number of people employed in agricultural production for all categories of farms $(L)$ and investments in capital assets aimed at the development of agriculture $(K)$ per 100 hectares of agricultural land is as follows:

$Q=108.45 * L^{0.57} * K^{0.20}$

The regression equation as a whole and all its parameters turned out to be statistically significant. Index of multiple correlation (0.76) indicates that the strength of relationship above the average, the index of multiple determination $R^{2}=0.57$. Based on the obtained net regression coefficients (elasticity coefficients), the following conclusions can be drawn:

- with an increase in the number of people employed in agricultural production in all categories of farms per 100 hectares of agricultural land by $1 \%$, the gross value added for economic activity "Agriculture, forestry, hunting, fishing and fish farming" will increase by an average of $0.57 \%$, providing that investments in capital assets will remain unchanged;

- with an increase in investments in capital assets aimed at the development of agriculture, per 100 hectares of agricultural land by $1 \%$, the gross value added for economic activity "Agriculture, forestry, hunting, fishing and fish farming" will increase by an average of $0.20 \%$, providing that that the number of employed in all categories of farms will remain unchanged. 
Obtained results of the model confirm the priority of the factor of number of labor resources for the volume of agricultural production.

Sum of the exponents is less than one, hence the function reflects a diminishing return, that is, an increase in resources outstrips an increase in output, i.e. we have a negative effect of expanding production.

\section{RESULTS DISCUSSION}

The use of the grouping method is often found in the scientific literature. At the same time, the study of the influence of natural factors is of great relevance. For example, in the reference source [4], the countries are classified according to the level of development of ecological and economic systems. In another study, grouping of the regions of the Russian Federation according to the value of the inclusive green growth index made it possible to identify an inverse relationship between the development of agriculture and emerging problems in the field of environmental protection [5]. In the study [6], several groups of regions were distinguished, differing in soil and climatic and economic conditions of management, as well as in the efficiency of the agricultural sector. The author notes that "in regions with unfavorable agricultural conditions, the agricultural sector is ineffective even if additional investments are attracted. Nevertheless, given the low population density, the industry needs the state support as the most important area of rural development" [6]. The authors of the article agree with this statement, that despite the unfavorable conditions for farming, state support of these regions is needed in order to preserve the rural lifestyle and rural areas, which is of great importance for the country's geopolitical security.

At the state level, the issue of sustainable development of rural areas and the influence of natural and climatic conditions on their development is also given great attention. So, in the strategy for sustainable development of rural areas of the Russian Federation for the period up to 2030, natural and climatic conditions are considered as the potential or limitation of the development of rural areas. Depending on the different conditions for farming and on the nature of the development and agricultural use, 4 types of subjects of the Russian Federation are distinguished. For example, for regions of the first type with a predominantly agricultural specialization of rural areas, favorable natural and social conditions for its development, it is proposed to use measures to support all types of businesses in rural areas that create jobs, small businesses and all forms of self-employment and for regions of the fourth type with a weak focal development of rural areas and unfavorable natural and climatic conditions for its development, measures are proposed for the development of small business. Thus, the developed approaches to the typification of personal subsidiary plots can be used in the formation of state policy for the development of rural areas.

On January 27, 2015, the Government of the Russian Federation approved the "Rules for classifying the territories as unfavorable for agricultural production", where climatic conditions are one of the criteria for classifying territories as unfavorable for agricultural production. The criterion based on natural conditions is the presence of agricultural land located at an altitude of more than 600 meters above sea level and/or on slopes with a steepness of more than 15 percent, and on the basis of climatic conditions - presence of territories prone to severe droughts and presence of territories prone to water logging, which is characterized by a hydrothermal moisture coefficient calculated on the basis of data for a period of at least 20 years.

The disadvantage of the study carried out by the authors is that other properties of the climate are not taken into account: moisture supply, the photosynthetically active part of radiation, which would allow for a better grouping by agroclimatic resources. Thus, in [7], a statistical assessment of the impact of climate warming on gross harvests and crop yields in each region of the Russian Federation was carried out. For the influence of climate warming, along with the average monthly sum of temperatures for 5 months of the growing season, such indicators as the amount of precipitation and relative humidity for April-August were taken.

Many foreign scientists, along with natural conditions, use many other variables to develop a typology, including labor resources. In work [8], a new procedure for typology of agriculture was developed and implemented, taking into account the influence of spatial effects (proximity of spatial units and their agricultural activities, the effect of neighborhood) on the distribution of types of agriculture by regions or countries. As one of the variables, signs that characterize labor resources and their quality are used: the number of workers per 100 hectares of agricultural land, the level of education, age, and the proportion of women who manage a farm.

Importance of studying labor resources by type is also confirmed by European scientists [9], who identified five types of small farms by the method of cluster analysis. Based on this analysis, they characterized the composition of labor resources by sex, age, higher education, use of family or hired labor, according to the degree of dependence on the type of hired labor, and also evaluated labor productivity as the ratio of income to the number of workers in full-time equivalent. The typology developed provides a more complete picture of the diversity and nature of small holder farming in Europe.

On the contrary, Brazilian scientists in their study [10] divided farmers into different types according to their perception of environmental problems and weather 
modification using the dominant component analysis and the cluster analysis. The results of this study can be used to improve the effectiveness of policy and strategy development to accelerate the adoption of sustainable agricultural practices, which in turn can mitigate the effects of climate change, minimize the degradation of natural resources and increase food production.

\section{CONCLUSIONS}

The study of the regions of the Russian Federation revealed the dependence of the distribution of labor resources on climatic conditions for farming.

The results of the formed Cobb-Douglas model confirmed that labor resources are indeed one of the main factors in agricultural production.

The developed typology of regions can be useful for the development of state policy measures in order to preserve the geopolitical security of the country and the development of rural areas. For this, first of all, it is necessary to attract labor resources not only to zones with favorable conditions for farming, but also to zones of risky farming, through investment and state support of agricultural producers in such territories.

\section{REFERENCES}

[1] A.E. Shibalkin, 'Monitoring demographic processes in rural areas', Russian Agricultural Economics 6 (2020) 109-113. DOI: https://doi.org/10.32651/206$\underline{109}$

[2] B.Sh. Dashieva, A.V. Ukolova, Statistical Observation of Labor Resources in Agriculture, Reports of the TSHA: Collection of Articles Issue 292 Part III (2020) 275-281, Publishing house RSAU-Moscow Agricultural Academy, Moscow. Retrieved from: https://www.elibrary.ru/item.asp?id=32297019

[3] A.P. Zinchenko, A.V. Ukolova, Yu.N. Romantseva, Labor resources of agriculture in Russia (based on the results of the All-Union Agricultural Policy 2006), Economics of agricultural and processing enterprises 3 (2009) 57-60. Retrieved from: https://www.elibrary.ru/item.asp?id=11773229

[4] A.E. Kharitonova, A.E. Ulyankin, Impact of meteorological conditions on the ecologicaleconomic systems of Russia, Proceedings of the 2nd International Scientific and Practical Conference on Digital Economy (ISCDE 2020), Atlantis Press Vol. 156 (2020) 207-212. DOI: https://doi.org/10.2991/aebmr.k.201205.034

[5] V.V. Demichev, Sustainable Development of Agriculture in Russian Regions on the Basis of Inclusiveness, Proceedings of the international scientific conference Hradec Economic Days 2020, University of Hradec Králové, Hradec Králové, Czech Republic Vol. 10(1) (2020) 85-94. DOI: https://doi.org/10.36689/uhk/hed/2020-01-010

[6] Yu.N. Romantseva, M.V. Kagirova, D.F. Galyautdinova, Application of statistical methods in assessing the role of agriculture in the formation of regional income, Proceedings of the 2nd International Scientific and Practical Conference on Digital Economy (ISCDE 2020), Atlantis Press Vol. 156 (2020) 281-285. DOI: https://doi.org/10.2991/aebmr.k.201205.036

[7] A.P. Zinchenko, O.B. Tarasova, N.I. Pyzhikova, Statistical study of the impact of climate warming on productivity, Proceedings of International scientific conference "Metrological support of innovative technologies - ICMSIT-2020", Institute of Physics and IOP Publishing Limited, Krasnoyarsk, Russia, 2020, pp. 52071. DOI: https://doi.org/10.1088/1742-6596/1515/5/052071

[8] B. Głębocki, E. Kacprzak, T. Kossowski Multicriterion typology of agriculture: A spatial dependence approach, Quaestiones Geographicae 38(2) (2019) 29-49, Bogucki Wydawnictwo Naukowe, Poznań. DOI: https://doi.org/10.2478/quageo-2019-0021

[9] A. Guarína, M. Riverab, T. Pinto-Correiab, N. Guiomarb, S. Šūmanec, O. M. Moreno-Pérezd, A new typology of small farms in Europe, Global Food Security 26 (2020) 100389. DOI: https://doi.org/10.1016/j.gfs.2020.100389

[10] C.R. Foguesatto, J. A. R. Borges, J. A. D. Machado, Farmers' typologies regarding environmental values and climate change: Evidence from southern Brazil, Journal of Cleaner Production, 2019, pp. 400-407, DOI: https://doi.org/10.1016/j.jclepro.2019.05.275 